\title{
Vodafone: \\ The relationship \\ between brand image \\ and online marketing \\ strategies \\ $\mid$
}

Niaz Hasan Mahmud

Glasgow Caledonian University. United Kingdom.

PhD. Irene García-Medina

Glasgow Caledonian University. United Kingdom. irene.garcia2@gcu.ac.uk

ORCID: http://orcid.org/0000-0003-4424-3357

DOI: http://dx.doi.org/10.12795/IROCAMM.2018.i1.01

\begin{abstract}
The competition in global marketplaces is progressively increasing due to a large number of local players that form the telecom industry. For this reason, it is essential for companies to establish a strong brand image to maintain its position in the market. Vodafone has been one of the fastest growing companies in the world. Nevertheless, it still holds the number two position in the telecom European market and the sixth, in the international sphere. This aspect encourages us to dig into which factors need to be considered to reach the zenith. We have focused on the international online marketing strategies that are used by telecommunication companies to establish and enhance brand image in the
\end{abstract}

global market. With the example of Vodafone, the research concentrates on the intricacies of the relationship between brand image and online marketing strategies in order to enhance brand image internationally, in the context of the global telecom sector. For this purpose, two detailed online surveys were conducted to gather opinion about the effects of online marketing strategies on brand image. It also aims to find the gaps in the online strategies and improve them in order to boost up the brand image of Vodafone.

Keywords: Brand Image; International Marketing; Vodafone; Online Marketing. 


\section{Introduction}

Nowadays, businesses have expanded beyond domestic boundaries, and so have increased the needs of strong marketing tools to gain recognition and brand image in the global market. According to 'The GSMA Mobile Economy Report 2017', by the end of 2016, there were 4.8 billion unique mobile subscribers, which means that 'twothirds of the world's population had a mobile phone subscription' (GSMA 2017). The UK Telecommunication Industry is one of the oldest industries in Europe, which is characterised by fierce competition. It is among the largest industries in the world, which has shown a remarkable growth in the mobile and broadband sector. In 2016, there were '25.3 million UK fixed broadband connections', compared with 2015, an increase of $542 \mathrm{k}(2.2 \%)$. In addition to this, 'mobile telephony services generated $£ 3.9$ bn in retail revenues' (Telecommunications Market Data Update Q4, 2016).

Vodafone, based in the UK, is one of the largest telecom service providers internationally. This organization has marked its presence globally in both developed and developing nations, serving more than 460 million customers worldwide (Vodafone Annual Report, 2016). In the global sphere, it ranks sixth after Deutsche Telekom and is the second most valuable brand in the European home market. In the UK telecom sector, strong players like British Telecom (BT), the oldest player in this industry, are giving tough competition, which emphasizes the need of enhancing brand image. In the 21st century, the penetration of internet in all aspects of modern life makes it an important communication tool, where not only individuals can communicate with each other but also large companies, such as Vodafone, have access to millions of customers at a click. This has been allowed by legislations moves like the one where 'the US Congress rescinded the Obama administration's privacy restrictions. This enabled telecom providers to collect and share customer data, treating the telecoms more like Google or Facebook than like utilities' (BrandZ $^{\text {TM }}$ Global Top 100 Most Valuable Brands report, 2017).

As the online marketing strategies should be framed strongly in order to promote a positive brand image and recognition in the global market, this research outlines the need for understanding the strategic importance of various online effective promotion strategies to enhance brand image internationally, in the context of the global telecom sector. It not only involves understanding the enhancement of electronic interactions with the customers to build a positive brand image, but also the right effective promotion strategies for gaining recognition. In regard to this, we have set a fourfold objectives for our research (1) To evaluate the growing importance of online 
marketing strategies in the international marketing. (2) To study the relationship between online international marketing strategies and brand image. (3) To identify the branding and international online marketing strategies used by Vodafone. (4) To find the gaps in the online marketing strategies and improve them in order to boost up brand image of Vodafone.

\section{Conceptual framework}

\subsection{Gathering three concepts: Brand image, international marketing and online marketing}

Online marketing has taken the centre position of most of the organisations and many of them are foregoing the use of traditional media for marketing (Newlands, 2011). Thus, the study of the relationship between online marketing and brand image has gained even more importance for many researchers. Online marketing, as a way for developing brand image, has become important in the era of globalisation (Amaeshi, Adi and Amao, 2006; Aggrawal et al., 2017). This is because it is the most convenient and cost-effective way to enhance and develop brand image not only in the domestic market but also in the international market (Young, 2005; Burmann et al., 2017). Busy time schedule and certain life style have restricted the customers from visiting the stores physically. As a result, it becomes difficult for the organisations to build brand image, says Roberts \& Zahay (2012). Thus, online marketing helps in conveying the features and characteristics of the brand to the customers, even if they are unable to visit the stores physically (Wheeler, 2012).

'Building a brand image not only vitalizes a brand, but also helps people gain interest in the brand and brings loyalty from the consumers' (Budelmann, Kim and Wozniak, 2010). Marketing strategies are targeted to build brand image and this requires sufficient amount of promotions, which would help to create an acceptable amount of awareness and a suitable perception among the prospective and existing customers (Roberts and Zahay, 2012). To reach the global population today internet is the best possible solution; it brings brands closer to people with just a click. Often companies create a parent brand under which a wide range of products is identified (Bullas, 2014). Thus, branding forms a major part of the overall marketing and business strategies. A company or a brand that holds a very good image among the public is expected to capture a greater market share and gain a competitive advantage. In addition, several researches on brand image have found that a positive brand image 
leads to high level of brand loyalty. 'Brand image is the mental construct developed by the consumers on the basis of a few selected impressions among the flood of the total impressions', says Bradbury (2012). Kotler (2012) has defined brand image as a group of ideas, impressions and beliefs that a consumer holds behind a specific brand. In addition to this, brand is the attribute of the business firm or organisation the customers or potential customers identify with, and this definitely implies global repercussions. Kitchen (2002) and Young (2005) point out that international marketing and branding are 'integrated concepts'. To develop and analyse brand in international markets, it should have some global significance to which the global population can directly relate to, without cultural or social factors creating an obstacle (Remenyi, 2012). Thus companies should include various factors like customer analysis to understand the trends, motivation, unmet needs, segmentation, etc. and the companies also need to carry out competitive analysis in the market through brand image, brand identity, strategies, strengths, vulnerabilities and the self-analysis too (Hollensen, 2014).

Kotabe and Helsen (2012) define international marketing as the ability of the company to market their products and services in almost all countries. With the emergence of the internet, this reach has become extensive. 'Despite the rapidly changing digital media and technology landscapes, [...] marketing fundamentals have remained constant and are even more essential', helping to 'differentiate businesses given the intense competition' (Chaffey and Smith, 2017). On the other hand, brand represents and characterises a company, a product and/or service, in order to make them relevant and distinctive to the consumer. Brand identity is a very important aspect (Kapferer, 2008), which determines brand communication with the customer. Strong brands acquire the capability to integrate all aspects of a product into an effective whole. Thus to communicate this identity marketing strategies have to be effectively formulated, being the WoM especially important (Niros et al., 2017), virtually extended to social media networks (Hudson et al., 2016; Clark et al., 2017).

\subsection{UK Telecom industry and investment in international marketing}

The UK Telecommunication Industry has pioneered several business models in order to distribute digital content. For instance, 'The BrandZ ${ }^{\text {TM }}$ Global Top 100 Most Valuable Brands report 2017' outlines the attempt that telecom providers are doing to move from just being 'voice and data providers and become consumer-facing content and 
entertainment brands'. Some of this Major brands, like the British company Vodafone, 'took significant initiatives to advance this goal and to position themselves for leadership in the Internet of Things' offering their customers free trials on multimedia streaming content platforms such as Netflix or HBO. In 2016, the expenditure on internet advertising of the UK Telecom Industry increased by $16.4 \%$ to $£ 8.6 \mathrm{bn}$ (The Communications Market Report: UK, 2016). 'The popularity of smartphones is reflected in substantial year-on-year increases in mobile advertising spend per head, with the UK maintaining its position in second place ( $£ 39.63$ in 2015 ) behind the US $(£ 42.02)^{\prime}$ (The Communications Market Report: International, 2016). These figures demonstrate that there is a growing importance of international online marketing in the UK Telecom industry. Although most of the UK Telecom companies enjoy an excellent brand image in the international market, they are continuously facing the challenges of other international brands. For instance, the UK Telecom Industry investment on internet advertising is overtake for emerging countries like China, that assigned in 2016 the $53 \%$ of all its advertising spend to online marketing, beyond the expenditure made by the UK (48\%) (The Communications Market Report: International, 2016). In order to maintain its international position and further expansion across the globe, UK Telecom providers need to potentiate their brand image (Brew \& Lucas, 2009). In the current scenario, a customer is no more restricted with limited alternatives. Despite price, quality and customer service matters, it is the brand image which plays a major role in influencing consumer buying decision. 'Brand image is a set of beliefs of the customers, held about a specific brand' (Wheeler, 2012). In other words, brand image represents the organisation's character and highlights its vision and mission to the customers. With the technological advancement and increased disposable income of the customers over the world, online marketing has become the best platform for an organisation to portray its character and derive direct sales through e-commerce (Sinkovics and Ghauri, 2009). Thus, international online marketing is the most effective way to develop brand image, especially in the UK Telecom Industry which has the required financial and human resources to invest in establishing effective international online marketing strategies (UK Telecommunications Report Q3, 2016).

\section{Research methodology}


This research has followed the positivist paradigm to study the effect of international online marketing strategies on brand image. In combination, a quantitative approach has been implemented to analyse the facts associated with the evaluation and connection between these two variables. As for data collection, two independent questionnaires were elaborated. Each template was composed of ten close ended questions. The sample was integrated by 100 people divided into two groups: Vodafone Digital Marketing Managers and customers of the brand. This second group was identified through Vodafone online community. The managers were contacted through the professional social network LinkedIn. The sample population was picked randomly, identifying participants from four countries: UK, USA, India and China. The questionnaire was sent by e-mail in January 2017 and, with the information obtained, it was carried out an 'exploratory data analysis' in March 2017. It was electronically analysed with MS Excel and this programme was also used to generate graphs and diagrams to illustrate the data collected

\section{Data findings and analysis}

\subsection{Questionnaire A: Survey to Vodafone's customers}

\subsubsection{Demographic profile of the Customers}

1. Age of participants. The main age group of customers that responded to the survey were between 18 and 25 years old. They constituted about $43 \%$ of the customer sample population. $17 \%$ of the customers who participated, belonged to the age group of 26-35 years old. The age group of 36-45 represented $30 \%$ and is the second largest group in the sample. The last $10 \%$ was represented by people of +45 . Youngsters are the predominant age group, as this segment of the population is used to check regularly social media networks and to surf the Net. They also form the largest group of customers in developing countries like India. The low response of the 26-35 age group, the core workforce, was concluded to be due to their reluctance to participate in online surveys. In the same line,+45 age group has a lack of interest and limited use of social networks (Remenyi, 2012). 
2. Gender of the participants. A significant lower number of females participated in the survey. They only constituted $37 \%$ of the total customer sample population, and the rest $63 \%$ was dominated by male gender. Nevertheless, this sample is relatively small to comment on the social media use pattern between males and females. The response inclines towards an understanding that females were less interested in participating. It is necessary to highlight the point that equal number of males and females were contacted by the researcher via Facebook to avoid any bias.

3. Occupation of the participants. The majority of the respondents, $53 \%$ of the sample, was represented by fellow students from various universities in the three chosen countries. The response rate was high among them as they are quite familiar with answering surveys for academic purposes and secondly, their use of social networks like Facebook is considerably high. With the smart phone revolution, globally access to internet and mobile operator has become vital. $23 \%$ of the respondents were working as telecom employees, $17 \%$ was in the other categories: unemployed or homemakers, and $7 \%$ of the respondents were entrepreneurs or owned a business.

Graphic 1: Type of occupation

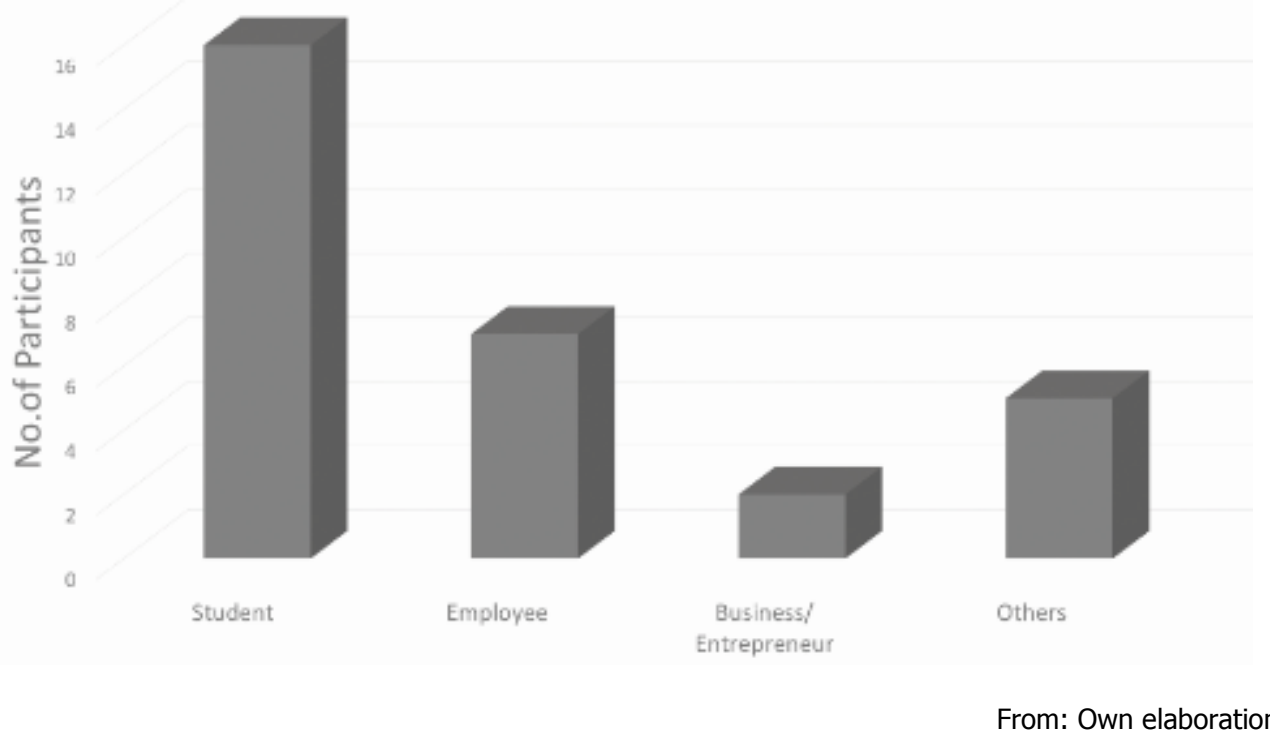




\subsubsection{Questions related to the Telecom provider Vodafone}

4. Were you using any other service provider? This question highlights the brand visibility in the market that encouraged people or prospective customers to shift telecom service providers. This shift is often aligned with various reasons and personal preferences. Thus in this customer survey was identified that only $27 \%$ of the people were using other service providers before they became consumers of Vodafone. $73 \%$ of the respondents were Vodafone customers from the very beginning of the consumption. Literature highlights that the shift is often significant when brand awareness is high. The number of existing customers of Vodafone is high, but a limited number of people in the sample has shifted operators different than Vodafone. In order to attract other prospective customers and increase its market share in the nearly mature markets, Vodafone has to implement new marketing strategies, especially internationally, as countries like China or India require long lasting competitive glocal strategies.

5. What attracted you to be a customer of Vodafone? It is necessary to know what the customers of Vodafone really like about the brand or the service they provide, this would help Vodafone to analyse their strengths in the market.

\section{Graphic 2: What attracted you to be a customer of Vodafone?}

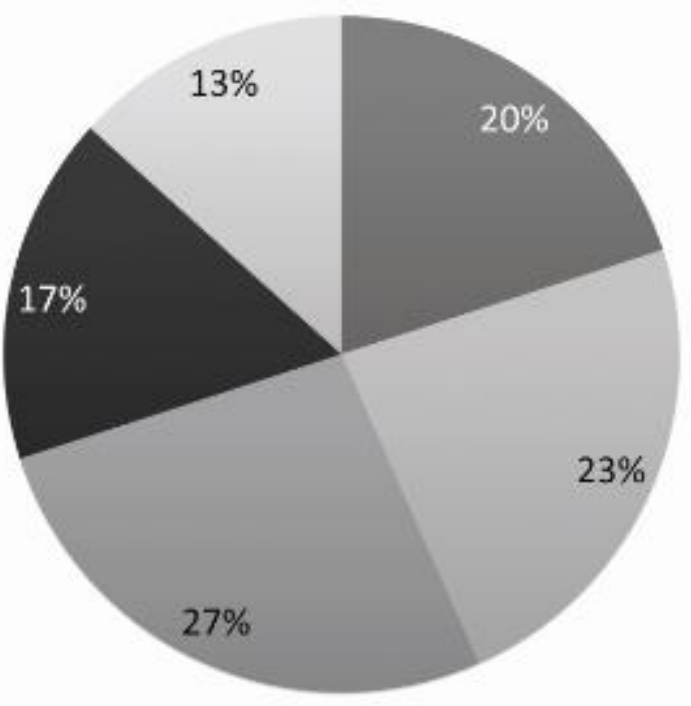

- Good reputation in the market

= Attractive online marketing

Excellent customer service

- Reliable network connectivity

= Others(attractive offer plans,customized offers etc.)

From: Own elaboration 
The data findings reflected that $27 \%$ of the existing customers were attracted to Vodafone because of its excellent customer service. $23 \%$ of the customers were influenced by the online marketing campaigns promoted by Vodafone, sharing digital content such as the famous advertisement fictional characters 'ZooZoo', created by Ogilvy \& Mather for the presence of the brand in India. 20\% of the sample population said that their leitmotiv was the reputation of the brand in the telecom market. On the other hand, $17 \%$ said that chose Vodafone over the other telecom providers due to its reliable mobile network connectivity and internet data services. Finally, $13 \%$ of the segment outlined other factors like prepaid and postpaid plans and personalised promotions to reward the customer loyalty.

6. How long have you been customer of Vodafone? Most of the survey customers, $53 \%$ of the sample, can be labelled as 'relatively new users', hiring Vodafone service from one to three years. $28 \%$ of the samples are 'ardent customers', using the products long enough, more than three years at a stretch; they can be also called 'loyal customers'. $19 \%$ of the customers are 'nascent', as they have been using the service for less than a year. This means that Vodafone has captured a large range of market share in the past five years, also strengthen by the internet marketing growth and its accessibility globally. Its current customers' loyalty has been reinforced with extra services and a wide range of online facilities that have added value to this telecom provider. $19 \%$ of the sample, who has recent joint Vodafone family, should be provided with additional service support and other marketing strategies to foster their loyalty as customers in the long run.

\section{Are you aware of the various marketing activities undertaken by}

Vodafone globally? Vodafone has undertaken numerous online and offline marketing strategies to hold the attention of its customer base and attract new prospective customers worldwide. It applies marketing strategies based on a deep study consuming needs and preferences of the operating country. $27 \%$ of the sample was strongly aware of the different marketing activities carried out by Vodafone globally. $37 \%$ of the customers were aware of the locally ongoing activities. $23 \%$ admitted having some relevant knowledge about the activities, not finding it decisive to become a Vodafone customer. Finally, the $13 \%$ was not yet aware of any of the activities offered to Vodafone clients. 


\section{Which type of online sources you generally use to gather information} about Vodafone's services? Facebook and Twitter were the two major online sources identified, followed by online advertisements on YouTube and other websites as well as in Vodafone official website. Other participants added pop-up advertisements on frequently visited webpages. Kotabe and Helsen (2012) outline that the rate of internet users are rapidly growing globally and the online avenue is the most cost effective way to reach international customers. For a mobile service provider like Vodafone, it is necessary to increase its presence in social media platforms, daily visited by its customers.

\section{Graphic 3: Types of online sources generally used to gather information about Vodafone's services}

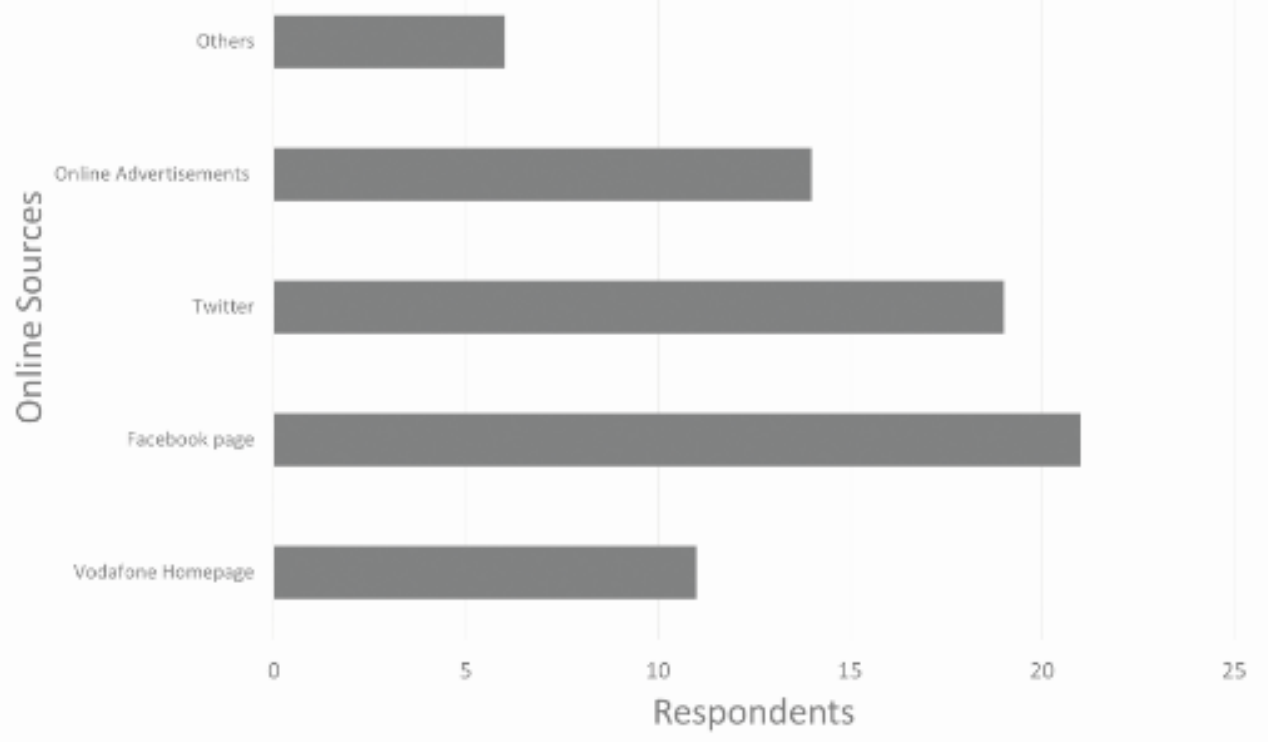

From: Own elaboration

\section{What comes to mind first when you think of Vodafone? $37 \%$ of the} respondents said that a global brand image is what they think of while they visualise the brand. $30 \%$ pointed out that Vodafone reflected the image of a reliable mobile operator. $20 \%$ could immediately think of their powerful tagline or its brand fictional ambassadors in India, ZooZoo advertisement characters. Finally, a 13\%, instantly thought about their customer assistance service. 
Graphic 4: What comes to mind first when you think of Vodafone?

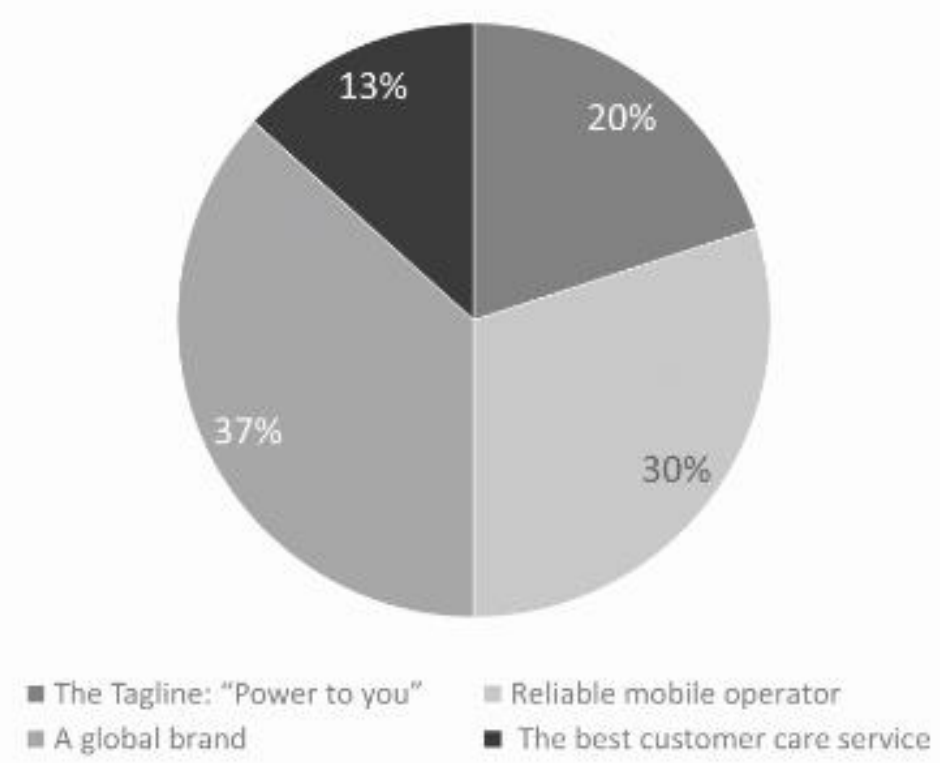

From: Own elaboration

\section{How to improve Brand image of Vodafone through online marketing?}

When the survey customers were enquired about how Vodafone should improve its brand image through online marketing, most of the customers pointed out that Vodafone should create specific customer assistance websites for interaction. Creation of attractive online campaigns and viral social media posts were other favourite options selected. Some of the participants said that Vodafone should highlight their CSR initiatives to create a positive image globally. Various authors have pointed out that the promotion of CSR initiatives should be done subtly to avoid misjudgement of the customers (Sinkovics and Ghauri, 2009). 
Graphic 5: How to improve brand image of Vodafone through online marketing?

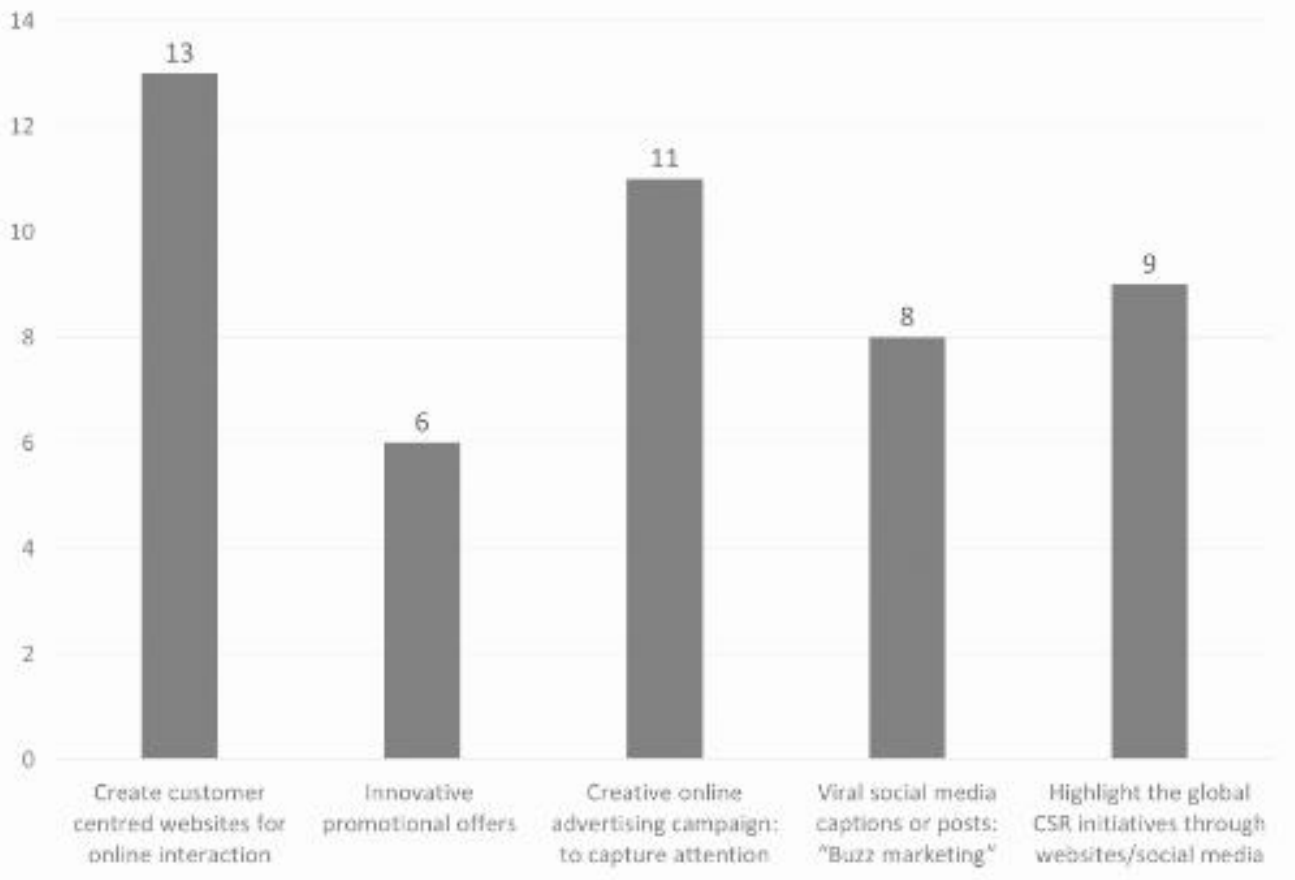

From: Own elaboration

\subsection{Questionnaire B: Survey to managers working for Vodafone}

\subsubsection{Demographic profile of managers}

1. Age. $40 \%$ of manager respondents were in the age group of 27 to 35 . As there is usually a major presence of this age range in businesses' Digital Management Department because of their understanding of the intricacies existing in this online environment, as Carpenter and Weikel (2011) suggest. Only $10 \%$ of the managers were $+45,30 \%$ were between 22 and 26 and $20 \%$ was represented by people from the age group of $36-45$.

2. Designation of the surveyed managers in Vodafone. A total of ten managers replied, out of the twenty initially contacted. In regard to their position, three of them were Social Media Managers, four were E-Marketing Managers, one Brand Manager and two Online Marketing-Brand Communication Managers. Views from all of them were necessary to formulate the existing perception within Vodafone as well as because of their connection with the field of this research. 


\subsubsection{Questions related to the Telecom provider Vodafone}

\section{What kind of branding strategy does Vodafone follow?}

$60 \%$ of the respondents agreed that Vodafone follows a corporate branding strategy where all its products and services are provided under a 'gigantic brand name'. 30\% of the managers also said that Vodafone is an 'umbrella brand' which is a similar concept as 'corporate branding', where a single name is used for all products. $10 \%$ of the managers said that line extension brand strategies were used where new products are branded under existing products as an extension. During the data analyisis process, it was perceived what Kapferer (2008) mentioned about how often brand and its strategies have a thin line of difference which makes them indistinguishable; as some of the survey managers had different points of view about which branding strategy was following Vodafone.

\section{Graphic 6: Branding strategy of Vodafone}

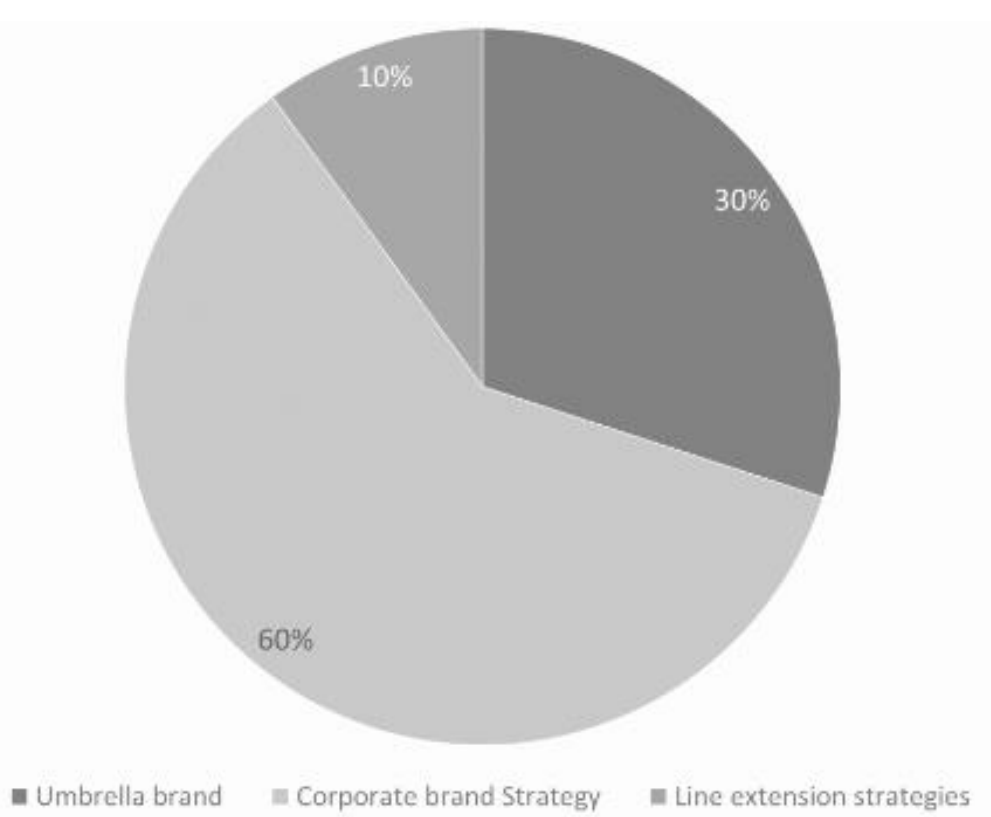

From: Own elaboration

4. Is there a need to link online marketing strategies to international marketing, or Vodafone should focus locally on their activities to increase local impact? As internet is a global platform, online marketing is often planned by multinational companies just focusing on global population needs. Thus, $50 \%$ of the managers said that there is a relevant need to link online marketing strategies to 
international marketing. $30 \%$ of the respondents specified that Vodafone should concentrate on the localised needs and promote regional offers or commercials which are appreciated within the border of a country, as the impact is often stronger. $20 \%$ said that Vodafone should combine both to serve the 'glocalized' needs.

\section{Do online marketing strategies only have positive impacts on the global}

market? $70 \%$ of the managers agree that online marketing strategies have only positive impacts on the company. $30 \%$ mentioned that not always the result is positive because of negative publicities or bad reviews. They tend to spread widely, affecting negatively to the company reputation.

\section{What components of internet marketing should be majorly used by} Vodafone to create a brand image in the international market? The majority of the survey respondents chose social media as the most favourable component to create a brand image internationally. Social networks can not only interact with the customers but also keep them updated about the novelties related to Vodafone. Blogs and viral advertisements (featuring the fictional brand ambassador 'ZooZoo' in India) are also recommended by $30 \%$ of the managers. Vodafone official website, which is always updated, provides with a lot of information about its ultimate ventures and undertakings. SEO was the least favoured option because of it lack of interaction with the customer and the difficult relation equation investment-effective impact.

\section{Graphic 7: Which internet marketing components should be majorly used by Vodafone?}

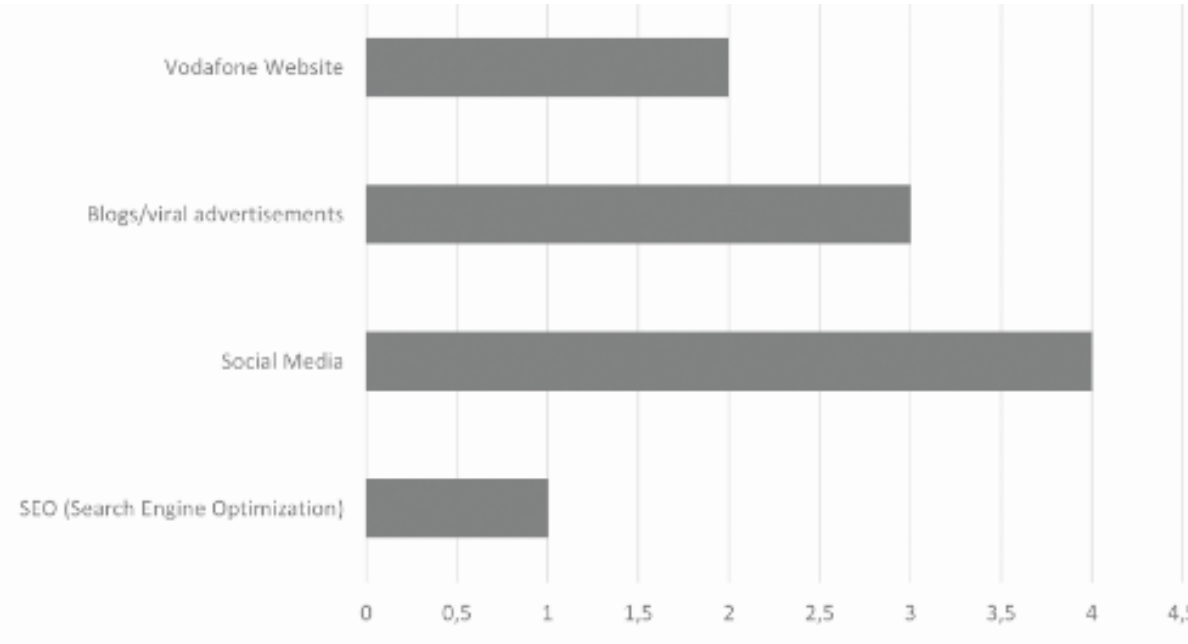




\section{Which online strategies used by Vodafone help to create a brand image in the international market?}

As in the previous question, the majority of managers agreed that social media is the most preferred online strategy to create a valued brand image in the international market. Viral advertisements and blogs were also recommended by the managers as a way of producing content related to the brand. SEO, as a brand image marketing strategy, was supported by a non-significant number of managers.

Graphic 8: Which online strategies used by Vodafone help to create a brand image in the international market?

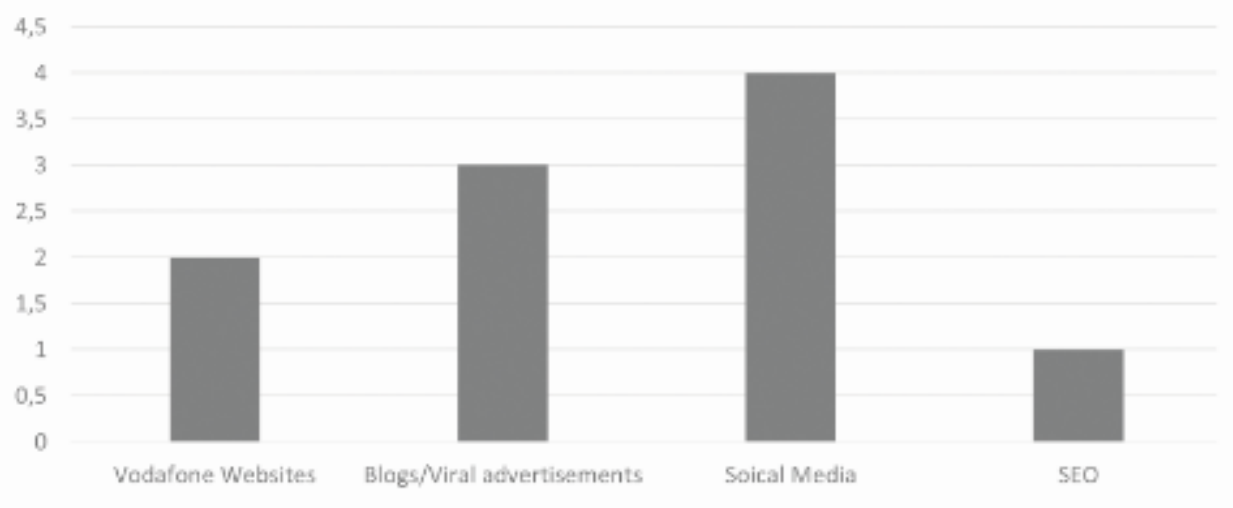

From: Own elaboration

\section{What non-functional benefits do you think the brand Vodafone provides} to its customers? The brand Vodafone claims to provide a variety of non-functional benefits. An equal number of managers believe that Vodafone provides recognition, confidence and status. $30 \%$ of the managers feel that trustworthiness is the most important benefit that Vodafone has been able to build and provide its customers over the years. $10 \%$ of the managers outline the feeling of belonging to the company through its brand image and positive interactions with its customers that this telecom company has managed to provide. Thus, managers express that the brand has been able to occupy a positive position in the mind of its clients. 
Graphic 9: Non functional benefits of the Vodafone brand?

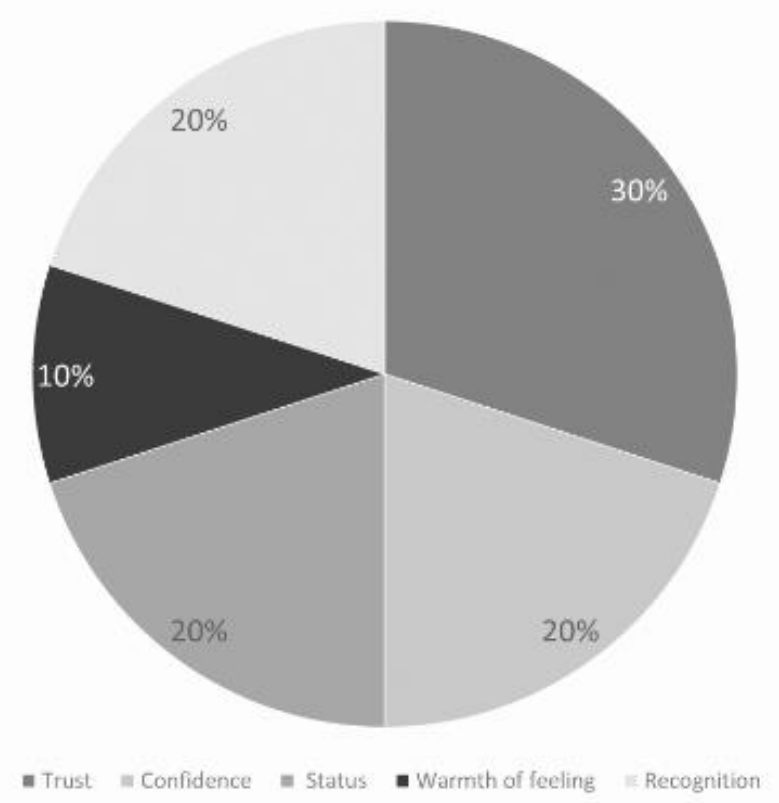

From: Own elaboration

\section{How will online international marketing strategies of Vodafone help in} the long run? Vodafone frames its marketing objectives to survive in the international market for a long period of time. When enquired about how online marketing strategies would help Vodafone in the long run, most of the managers said that it would result in market leadership globally and increase its international reach. Currently, Vodafone is operating in 30 countries independently and has a scope of continue its international expansion so these online strategies would help the company to enlarge their customer base. Some of the managers said that long term profit and sustainable competitive advantage could also be achieved by implementing the right set of online marketing strategies.

Graphic 10: Long run benefits of online international marketing

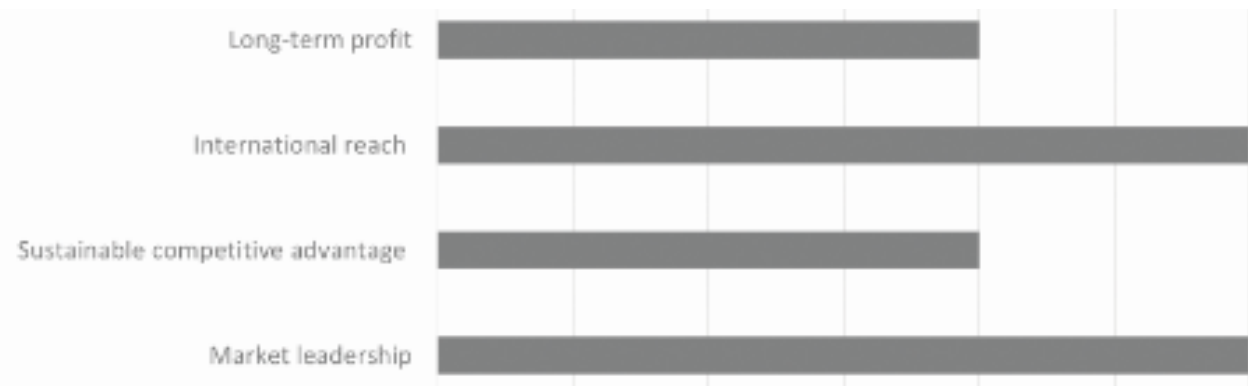

From: Own elaboration 


\section{How can Vodafone improve its international online marketing strategies} to enhance brand image in the global market? Vodafone has been trying to increase its global presence, thus it requires enhancing its existing online marketing strategies to build a stronger brand image in the countries where it does not have direct operations. The radar diagram plotted below shows that 5 out of the 10 surveyed managers indicated that it would be possible through implementation of a stronger social media strategy. Three of the managers indicated that Vodafone could improve its brand image by formulating a multilayered strategy where global needs, local needs and personal needs would be equally prioritised, and the online strategies should be formulated in a differentiated manner to target the needs and create demands globally. Online direct interaction with customers and prospective customers should also be increased, according to the suggestion of $20 \%$ of the managers.

Graphic 11: How can Vodafone improve their international online marketing strategies to enhance brand image in the global market?

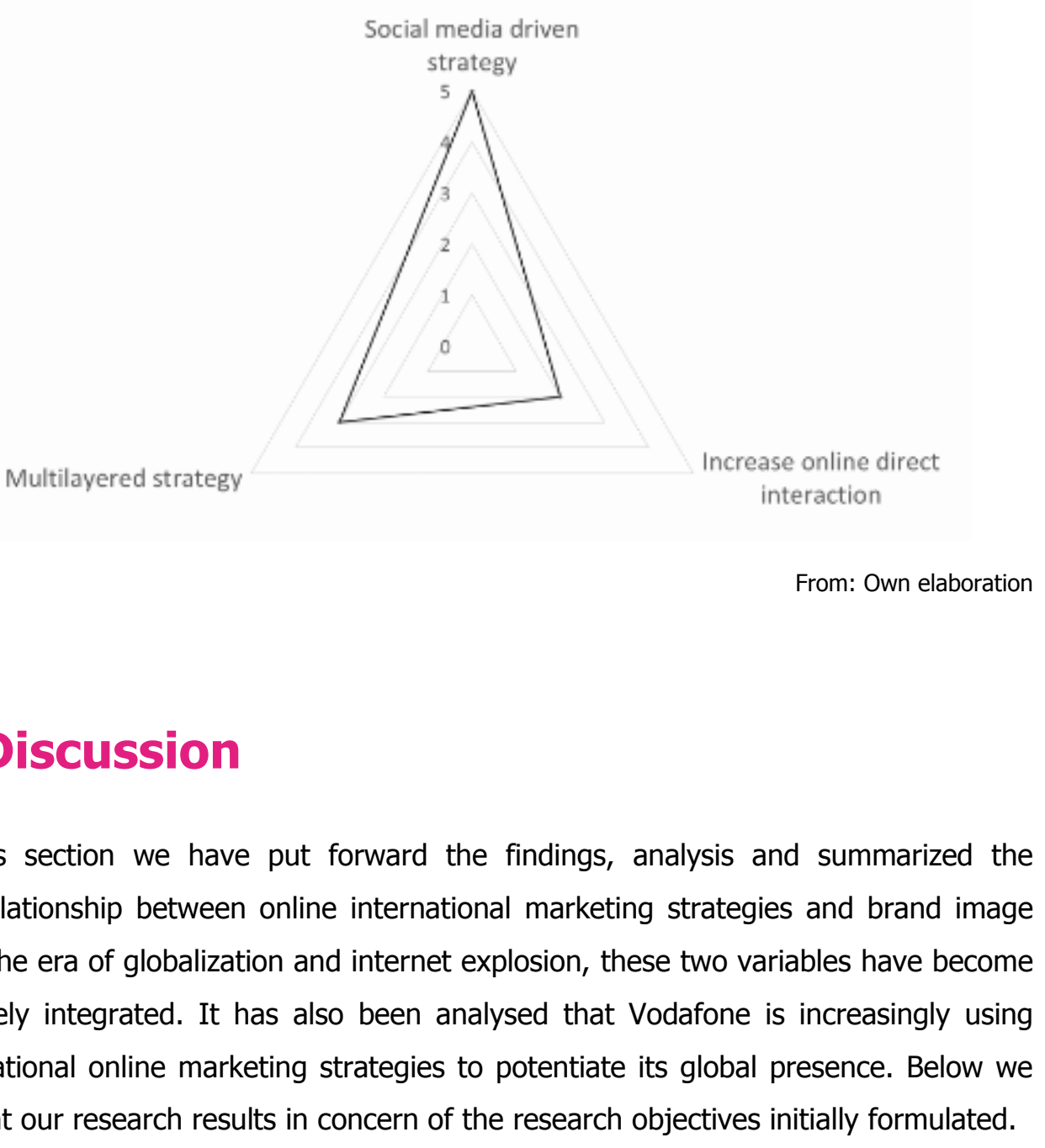

\section{Discussion}

In this section we have put forward the findings, analysis and summarized the interrelationship between online international marketing strategies and brand image as in the era of globalization and internet explosion, these two variables have become intensely integrated. It has also been analysed that Vodafone is increasingly using international online marketing strategies to potentiate its global presence. Below we present our research results in concern of the research objectives initially formulated. 


\section{Objective 1: To evaluate the growing importance of online marketing strategies in the international marketing.}

The international sphere of business is immensely becoming competitive, forcing telecom companies to differentiate from their competitors, not only locally but also in the global market. In regard to this, online marketing strategists play an important role in multinational businesses. The manager-questionnaire survey results reveal that Vodafone emphasises its online marketing strategies due to the international promotion of the brand. $50 \%$ of the surveyed managers agreed to this interrelation between online marketing and international marketing. Sinkovics and Ghauri (2009) suggest that companies which are trying to expand their base beyond the domestic boundaries are majorly moving out of the cliché approaches or the traditional ways formerly used. At present, the ground can be tested virtually before the physical expansion analysing the demand of the brand and its products and services through its presence on internet. Foreign market characteristics are very different and require an analysis of the customer needs and trends as well as then, formulate the strategy to enter a new market. In regard to this, two different business perspectives of international marketing has emerged clearly. On the one hand, 'standardization' in the marketing strategy should be implemented in the international markets. Five out of the ten managers in the sample population have agreed that for Vodafone it is necessary to link their online marketing strategies to international marketing. The standardised marketing strategy not only helps to minimize costs of promotional activities but also helps to build a 'global corporate image' (Roberts and Zahay, 2012). The importance of online international business marketing strategy is growing with spread of globalization, where global markets have merged. The other concept of international marketing is of 'adaptation' according to literature, where there is a need for the online marketing strategies to suit the uniqueness of the local markets to create greater impacts on the minds of the customers. $30 \%$ of the e-marketing managers have agreed that the local strategies are vital, the rest of the managers responded that there is a need for Vodafone to merge the standardization and adaptation approaches of international marketing.

\section{Objective 2: To study the relationship between online international marketing strategies and brand image.}

Brand is one of the major drivers to attain a sustainable competitive advantage in the long run. Most of the customer respondents were students and only $27 \%$ of the customer sample had been using the services of other mobile operators before they shifted to Vodafone, which means $73 \%$ of the customers were from the initial stage 
clients of Vodafone. This establishes that Vodafone has a good ground image in all the three countries from where the participants belonged. In India, Vodafone has a very strong brand value says Copulsky (2012), and it has been possible through various promotional mechanisms, especially those applied on internet. When the researcher posed the question 'what comes to the mind first when people recall Vodafone', 37\% of the customers said that 'a Global Brand', which shows that most of the customers are aware of Vodafone's global footprints and this helps in building the frame of a global brand. Regarding the relationship between online international marketing and brand image, Budelmann, Kim and Wozniak (2010) discuss that marketing strategies are targeted to build brand image and this requires sufficient quantity of promotions, which would help to create an acceptable amount of awareness and a suitable perception among the prospective and existing customers. On the survey, managers were enquired about the impacts of online marketing strategies globally. $70 \%$ of the sample said that only positive impacts were possible while the rest $30 \%$ said that negative impacts could also be the outcome. The researcher analysed the reason behind this negative impact with the help of related literature available. It was found that, various authors were sceptical about the only positive impacts of online marketing. The negative publicity through social media is viral and can damage the image of the brand for a long duration (Copulsky, 2011; Kähr et al., 2016). 'Brands are under constant attack, and brand stewards must systematically understand the risks that their brands face, the potential impacts, and the options for managing these risks' (Copulsky, 2011). The majority of the customers said that they were attracted to Vodafone because of its excellent customer care service and good reputation in the market. The current use of smartphones have exponentially increased, existing a smartphone adoption of $51 \%$ of the global population (GSMA, 2017), so online strategies are the best method to grab attention and build a positive brand image by delivering good service and building a healthy relationship with customers.

\section{Objective 3: To identify the branding and international online marketing strategies used by Vodafone.}

$53 \%$ of the customers have been using Vodafone's services for a substantial period of time (one to three years). $28 \%$ have been using these services for more than three years; this reflects that Vodafone is able to mantain their customers. The branding strategy used by Vodafone was not very clearly reflected through the managerial questionnaire survey. $60 \%$ of the surveyed managers pointed out that Vodafone uses a corporate branding strategy where all its products and services are offered under a consolidated brand name. So agreed $30 \%$ of the managers, who selected the option 
of umbrella brand, a similar concept where all products are kept under a parent name, in this case, Vodafone. $10 \%$ of the managers said that line extension strategies were used by Vodafone. The prior result focusses on the corporate branding strategy developed by Vodafone. With reference to the uses given by Vodafone in this social media strategy, only $27 \%$ of the customers are strongly aware of the marketing activities undertaken by the company and $37 \%$ are moderately aware. The main types of online resources used by the customers to gather information after the analysis of the data, were found to be social media, especially Facebook, Twitter and online advertisements. $13 \%$ of the customers replied that they were not all aware of the marketing activities of Vodafone. Most of the managers suggested that social media is the best possible method to potentiate the brand impact through its online marketing strategy, as the use of social networking sites and the interactions and connections between people are daily high. In this digital environment, $30 \%$ of the managers agreed that non-functional benefits of Vodafone, such as trust, can provide with a positive value of the brand by its customers. This aspect would contribute to stimulate its good reputation, being their social media networks a potencial word-of-mouth publicity, which would reflect in attracting new clients to the brand. Online marketing strategies also have many long term benefits, idea shared by the majority of the surveyed managers, who suggested that they help to create market leadership and enhance the international reach of the brand, which would contribute to produce higher sustainable profits.

\section{Objective 4: To find the gaps in the online marketing strategies and improve them in order to boost up the brand image of Vodafone.}

Various gaps have been identified while analysing the questionnaire results conducted among Vodafone's customers and managers. On the one hand, the customers suggested that it was necessary to improve the brand image of Vodafone reinforcing online marketing techniques. For instance, they outlined the creation of Vodafone assistance websites where only customers would be attended in order to reduce the telephone assistance waiting time and as a way of improving Vodafone's online interaction with its customer base. This would enhance the trust on the brand as well as increase the warmth of feeling or belonging to this telecom provider. Advertising campaigns were also favoured by many of the customers to promote brand recognition in international markets. Viral social media posts or 'buzz marketing' were selected by a lower number of participants. It should also be outlined from the customer-questionnaire survey that some of the respondents wanted the company to highlight the CSR initiatives taken by them through social networks or websites. 
Whereas, the managerial questionnaire data analysis revealed that the managers preferred the social media driven strategy to enhance brand image in the market. The literature suggests that the social media spree has engulfed this generation's online marketing strategies which have also led to the creation of a mind blockage. Only twenty percent of the managers said that increasing online interaction would enhance the brand image, whereas majority of the customers opted for increase in customer centred online websites in order to enhance the clients assistance provided by Vodafone. Thus a gap in the agreement of chosing the suitable strategy for enhancing brand image was identified. Moreover, $30 \%$ of the managers hinted on creating a multilayered strategy that would enhance the globalized brand image.

\section{Conclusion}

The role played by online marketing strategies in the international marketing and building of the brand image is undeniable. Internet is a medium which not only helps to analyse the international market characteristics but also to identify the entry points in the market. With reference to this aspect, there are different types of business strategies that also give a competitive advantage in international markets, which include product strategy deals, distribution strategy and those focussed on promotional or brand communication strategy. Online marketing strategies are of growing importance to multinationals as they have a deeper reach than any other traditional marketing modes and enable to reach to concrete segments. Thus in our research the first objective was to evaluate the growing importance of online marketing strategies in the international marketing. The results show that Vodafone's managers prioritise social media strategy to build an effective global brand value. Newlands (2011) points out that various scholars have tried to formulate conceptual frameworks to understand the factors that influence or determined the scope of success or failure in the international markets, playing online marketing strategies an important role in determining this success. The managers of the sample also pointed out that online international marketing strategies have long run benefits such as the increasement of scope for international reach and helps them to obtain bigger market leadership.

In regard to how can brand image be improved with effective use of online marketing, the fact that the number of firms whose objectives are to increase their international presence, reflects on a higher number of competitors, both in the global and in the 
domestic market, so there is a need for the companies to create a niche for themselves. This is often referred to as 'brand'. Thus, companies need to focus on strategies to improve brand image in the international markets. As it was mentioned before, brand has many non-functional benefits such as trust, confidence, status, recognition etc. Vodafone, as a global brand, has been able to establish trust and recognition in the mind of its customers, as it was oultined in the results of the managers-questionnaire. Vodafone uses social media as their major internet marketing component, as revealed by the data analysis, which expand this values as well as information of the brand internationally, sharing the $37 \%$ of the surveyed customers the concept of Vodafone a 'a global brand'. Accordingly, this global brand image can be further enhanced with online marketing strategies. Most of its customers use social media to gather information about Vodafone, which set a scope for Vodafone to use this source in a better way. Additionally, the brand performance can also be measured with the review of effectiveness of the online marketing strategies and its direct implications on financial performance. Indeed, most of the managers were of the opinion that that they should rigorously implement a social media driven strategy.

Finally, regarding how can Vodafone improve its brand image by improving online marketing strategies, the customer survey showed that CSR is important due to the perception of brand image, as a number of the respondents expressed their interest in knowing about the CSR initiatives undertaken by Vodafone globally. This might elevate the brand image in the global market and the entry in new markets would be easier. The CSR marketing should be done subtly suggests Amaeshi, Adi and Amao (2006) as the promotion of CSR initiatives is often misinterpreted by many customers as a marketing tool, being the good intentions of the Company hidden. Thus, it is true that online marketing not always reap positive impacts. A $19 \%$ of the sample A were new clients of the brand, being necessary to offer them more than a product, so other initiatives carried out by the brand should be outlined in order to cater to the needs of the customer better and enhance trust and recognition globally. Far beyond the detailed information provided by the company in its corporative annual online reports, the digital world offers Vodafone a good way to spread CSR initiatives and its participants experiences, for example, in a subtle and creative way, with an international projection and getting involved in this duty to its customers and professional team. 


\section{Recommendations for future research}

Despite being a single-brand study, the research has been designed around three main concepts, important for the current trajectory of a company. With the survey conducted to a sample of customers and managers of a particular brand, it was measured how the brand image of Vodafone is perceived as well as putting together possible digital and international marketing strategies to reach to new markets. This approach opens future research lines to Vodafone, thus it could be recommended to conduct online market surveys to analyse what the customers are looking for in a telecommunication brand in order to inculcate better online international marketing strategies to increase global presence and positive brand recognition. In addition to this, with this Vodafone case study, we also aim to introduce specific mechanisms to measure the efficiency of online marketing strategies implemented via strategic indicators such as brand influence or financial performance, so they could be extrapolated to other telecom providers, even sectors, in order to enhance their bran image marketing policies.

\section{References}

Aggrawal, N., Ahluwalia, A., Khurana, P. and Arora, A. (2017) Brand analysis framework for online marketing: ranking web pages and analyzing popularity of brands on social media. Social Network Analysis and Mining 7(1), 21.

Amaeshi, K. M., Adi, A. B. C., Ogbechie, C. and Amao, O. O. (2006) Corporate social responsibility in Nigeria: Western mimicry or indigenous influences? Journal of Corporate Citizenship 24, 83-99.

BrandZ $^{\text {TM }}$ Global Top 100 Most Valuable Brands report (2017). Millwardbrown.com, http://www.millwardbrown.com/brandz/top-global-brands/2017, accessed 24 March 2017

Brew, A. and Lucas, L. (2009) Academic Research and Researchers. New York: McGraw-Hill International.

Budelmann, K., Kim, Y. and Wozniak, K. (2010) Essential Elements for Brand Identity: 100 Principles for Designing Logos and Building Brands. London: Rockport Publishers.

Burmann, C., Riley, N. M., Halaszovich, T. and Schade, M. (eds.) (2017) International IdentityBased Brand Management. London: Springer Fachmedien Wiesbaden. 
Carpenter, M. and Weikel, K. (2011) The Handbook of Research on Top Management Teams. Cheltenham: Edward Elgar Publishing.

Chaffey, D. and Smith, P. R. (2017) Digital Marketing Excellence: Planning, Optimizing and Integrating Online Marketing. London: Taylor \& Francis.

Clark, M., Black, H.G., Judson, K. (2017) Brand community integration and satisfaction with social media sites: a comparative study. Journal of Research in Interactive Marketing $11(1), 39-55$.

Copulsky, R. (2011) Brand Resilience: Managing Risk and Recovery in a High-Speed World. New York: Palgrave Macmillan.

Hollensen, S. (2014) Global Marketing. London: Pearson.

Hudson, S., Huang, L., Roth, M. S., and Madden, T. J. (2016) The influence of social media interactions on consumer-brand relationships: A three-country study of brand perceptions and marketing behaviors. International Journal of Research in Marketing 33 (1), 27- 41.

Kapferer, J. (2008) The new strategic Brand management: Creating and Sustaining Brand Equity. Upper Saddle River: Prentice Hall.

Kähr, A., Nyffenegger, B., Krohmer, H. \& Hoyer W.D. (2016) When Hostile Consumers Wreak Havoc on Your Brand: The Phenomenon of Consumer Brand Sabotage. Journal of Marketing 80(3), 25-41.

Kitchen, P. (2002) Managing reputation: global issues and problems. Paper presented at the 7th Annual Conference on Corporate and Marketing Communications; Antwerp, Belgium.

Kotabe, M. and Helsen, K. (2012) Global Marketing Management. New Jersey: John Wiley and Sons.

Kotler, P. (2012) Kotler on Marketing. New York: Simon and Schuster.

Newlands, M. (2011) Online Marketing: A User's Manual. New York: John Wiley \& Sons.

Niros, M., Pollalis, Y. and Niros, A. (2017) Effective marketing of mobile telecom services through brand personality: Empirical evidence from Greece. MPRA Paper 76477, University Library of Munich, Germany.

Remenyi, D. (2012) Field Methods for Academic Research: Interviews, Focus Groups and Questionnaires. London: Academic Conferences Limited.

Roberts, M. and Zahay, D. (2012) Internet Marketing: Integrating Online and Offline Strategie. Stamford: Cengage Learning.

Sinkovics, R. and Ghauri, P. (2009) New Challenges to International Marketing. Bingley: 
Emerald Group Publishing.

The Communications Market Report: UK (2016) Ofcom.org, https://www.ofcom.org.uk/_data/assets/pdf_file/0026/95642/ICMR-Full.pdf, accessed 6 June 2017.

The Mobile Economy Report (2017) GSMA, https://www.gsmaintelligence.com/research/?file=9e927fd6896724e7b26f33f61db5b9d5 \&download, accessed 6 June 2017.

Theodore, L. (2011) The Globalization of Markets. Harvard Business Review 61, 92-10.

UK Telecommunications ICT Market Reports (2017) Internet World stats, http://www.internetworldstats.com/eu/uk2.htm, accessed 13 July 2017.

UK Telecommunications Market Data Update Q3 2016. (2016) Ofcom, https://www.ofcom.org.uk/research-and-data/telecoms-research/data-updates/q3-2016, accessed 6 June 2017.

UK Telecommunications Market Data Update Q4 2016. (2016). Ofcom, https://www.ofcom.org.uk/research-and-data/telecoms-research/dataupdates/telecommunications-market-data-update-q4-2016, accessed 6 June 2017.

Vodafone Annual Report (2016) Vodafone, http://www.vodafone.com/content/annualreport/annual_report16/downloads/vodafonefull-annual-report-2016.pdf, accessed 6 June 2017.

Wheeler, A. (2012) Designing Brand Identity: An Essential Guide for the Whole Branding Team. Hoboken: John Wiley \& Sons.

Young, C. (2005) Advertising Research Handbook. Seattle: Ideas in Flight. 